\title{
Gas exchange in maize as a function of aeration porosity in a cohesive soil ${ }^{1}$
}

\author{
Trocas gasosas do milho em solo com caráter coeso em função de porosidades de aeração
}

\author{
Edilaine da Silva Marques ${ }^{2 *}$, Jaedson Cláudio Anunciato Mota ${ }^{3}$, Claudivan Feitosa de Lacerda ${ }^{4}$, Francisca \\ Gleiciane da Silva ${ }^{3}$ and Ricardo Espíndola Romero ${ }^{3}$
}

\begin{abstract}
Due to their physical characteristics, cohesive soils of either low or high aeration porosity can intensify limitations on plant cultivation. With the hypothesis that moist cohesive horizons where the soil has not yet reached a hard to extremely hard consistency may present a level of aeration porosity that affects gas exchange in maize plants, the aim of this study was to understand the influence of a cohesive horizon at different levels of aeration porosity on gas exchange in maize. The experiment was conducted in Fortaleza in the state of Ceará in a screened and covered environment, in a completely randomised block design with five levels of aeration porosity (AP) $\left(0.04,0.06,0.09,0.11\right.$ and $\left.0.13 \mathrm{~m}^{3} \mathrm{~m}^{-3}\right)$ and six replications, giving a total of 30 experimental units. The variables under analysis were intrinsic permeability $\left(K_{\text {air }}\right)$ and gas exchange. Increases in AP afforded an increase in $K_{\text {air }}$. The AP of 0.04 and $0.13 \mathrm{~m}^{3} \mathrm{~m}^{-3}$ reflected in lower values for the photosynthetic rate $(A)\left(24.54\right.$ and $25.50 \mu \mathrm{mol} \mathrm{CO} \mathrm{m}^{2} \mathrm{~s}^{-1}$ respectively) and internal $\mathrm{CO}_{2}$ concentration (140.72 and 118.66 $\mu \mathrm{mol} \mathrm{mol}{ }^{-1}$ respectively). With the increase in AP, stomatal conductance and transpiration were reduced by $18 \%$ and $13.6 \%$ respectively, while the increase in instantaneous carboxylation efficiency was $19 \%$, and intrinsic water use efficiency, $21 \%$. It was concluded that variations in aeration porosity in cohesive soils affected gas exchange in maize plants. The AP of 0.04 and $0.13 \mathrm{~m}^{3} \mathrm{~m}^{-3}$ reduced the value of $A$ due to non-stomatal and stomatal limitations respectively.
\end{abstract}

Key words: Cohesion. Hypoxia. Stomatal limitations. Non-stomatal limitations.

RESUMO - Os solos com caráter coeso, devido suas características físicas, podem intensificar as limitações ao cultivo de plantas, tanto em condição de menores quanto maiores porosidades de aeração. Tendo como hipótese que os horizontes com caráter coeso, na umidade que o solo ainda não atingiu a consistência dura à extremamente dura, podem apresentar porosidades de aeração que afetam as trocas gasosas em plantas de milho, o objetivo desse trabalho foi conhecer a influência do horizonte com caráter coeso, em diferentes porosidades de aeração, nas trocas gasosas do milho. O experimento foi conduzido em Fortaleza-CE, em ambiente cercado e coberto, sob delineamento em blocos inteiramente aleatorizado, com cinco porosidades de aeração (PA) $\left(0.04 ; 0.06 ; 0.09 ; 0.11\right.$ e $\left.0.13 \mathrm{~m}^{3} \mathrm{~m}^{-3}\right)$ e seis repetições, totalizando 30 unidades experimentais. As variáveis analisadas foram: permeabilidade intrínseca $\left(K_{\text {air }}\right)$ e trocas gasosas. Acréscimos na PA proporcionaram aumento na $K_{\text {air }}$. As PA de 0.04 e $0.13 \mathrm{~m}^{3} \mathrm{~m}^{-3}$ refletiram menores taxas fotossintéticas $(A)\left(24.54\right.$ e $25.50 \mu \mathrm{mol} \mathrm{CO} \mathrm{m}^{2} \mathrm{~s}^{-1}$, respectivamente) e concentrações internas de $\mathrm{CO}_{2}\left(140,72\right.$ e $118.66 \mu \mathrm{mol} \mathrm{mol}^{-1}$, respectivamente). Com o aumento da PA a condutância estomática e transpiração diminuíram $18 \%$ e $13.6 \%$, respectivamente, enquanto o aumento da eficiência instantânea de carboxilação foi de $19 \%$ e eficiência intrínseca do uso da água, $21 \%$. Conclui-se que a variação na porosidade de aeração em solos com caráter coeso afetou as trocas gasosas em plantas de milho, as PA de 0.04 e $0.13 \mathrm{~m}^{3} \mathrm{~m}^{-3}$ reduziram a $A$, devido limitações não estomáticas e estomáticas, respectivamente.

Palavras-chave: Coesão. Hipoxia. Limitações estomáticas. Limitações não estomáticas.

DOI: $10.5935 / 1806-6690.20210035$

Editor-in-Article: Profa. Mirian Cristina Gomes Costa - mirian.costa@ufc.br

*Author for correspondence

Received for publication 18/07/2019; approved on 08/10/2020

${ }^{1}$ Trabalho extraído da Tese do primeiro autor apresentada ao Programa de Pós-Graduação em Ciência do Solo, Universidade Federal do Ceará/UFC

${ }^{2}$ Instituto Federal de Educação, Ciência e Tecnologia do Maranhão/ IFMA, Campus Buriticupu-MA, Brasil,edilainemarques38@yahoo.com.br (ORCID ID 0000-0002-1535-4827)

32Departamento de Ciências do Solo, Universidade Federal do Ceará/UFC, Fortaleza-CE, Brasil, jaedson.mota@ufc.br (ORCID ID 0000-0002-1261-9754), gleiciane.silva27@gmail.com (ORCID ID 0000-0002-9216-3151), reromero@ufc.br (ORCID ID 0000-0001-8689-1390)

${ }^{4}$ Departamento de Engenharia Agrícola, Universidade Federal do Ceará/UFC, Fortaleza-CE, Brasil, cfeitosa@ufc.br (ORCID ID 0000-0002-5324-8195) 


\section{INTRODUCTION}

Coastal tablelands can be found along almost the entire coast of Brazil (REZENDE, 2000). In the soils of this geomorphological unit, agricultural crops generally show lower productivity due, among other factors, to the presence of cohesive horizons (REZENDE, 2000). The cohesive characteristic is a diagnostic attribute that indicates the state of soil consistency - from very hard to extremely hard when dry and friable, to firm when wet (SANTOS et al., 2018). Soils with similar behaviour are found in various countries, where they are known as hardsetting soils (DANIELLS, 2012).

One of the main characteristics of cohesive soils is the compact arrangement of the particles, with blocked and less-functional pores, which hinder the aeration process in the soil (MENEZES et al., 2018). This has a direct effect on the growth of crops, since when the soil water content is high, hypoxia or anoxia can occur and as a result, the photosynthetic process may be affected due to both stomatal and not-stomatal limitations (TIAN et al., 2019).

In addition, these soils usually have high values for root penetration resistance (PR) (MOTA et al., 2018). However, as the soil dries, this effect is enhanced, offering a greater obstacle to the roots, and hindering plant growth in soils where these horizons are present (DANIELLS, 2012).

Most studies of plant development in soils with cohesive horizons generally aim to relate penetration resistance to root growth in soils of very hard to extremely hard consistency (REZENDE, 2000). However, there are no studies that connect plant development with variations in aeration porosity in moist cohesive soils that have not yet reached a hard consistency.

In this context, the hypothesis is that cohesive horizons at a level of moisture where the soil has not yet reached a hard to extremely hard consistency may present a level of aeration porosity that affects the gas exchange of maize plants.

Therefore, the aim of this study was to understand the influence of a cohesive horizon maintained in a moist condition at different levels of aeration porosity, on gas exchange in maize plants.

\section{MATERIAL AND METHODS}

\section{Location of the experiment}

The experiment was conducted over 44 days from June to July 2018 in the city of Fortaleza, in the state of Ceará, at the Federal University of Ceará (N 9.856.790 m, E $547.351 \mathrm{~m}$, UTM zone 24 S), in a screened-off environment covered with clear plastic. According to the Köppen classification, the experimental area is inserted in a region of type Aw' climate, characterised as tropical rainy.

\section{Procedure for collecting and characterising the soil used in the experiment}

The soil used in the experiment was collected from the A and B cohesive horizons of a ARGISSOLO AMARELO (Ultisol) (SANTOS et al., 2018). For the A horizon, disturbed samples were collected with the aid of a shovel. These were subsequently air dried and passed through a 2-mm sieve to obtain the air-dried fine earth (ADFE) used in preparing the samples to determine the characteristic soil water retention curve (CSWRC) and the soil columns used in the experiment.

In the cohesive B horizon, undisturbed soil samples were collected in PVC tubes with an external diameter and height of $0.20 \mathrm{~m}$, and in $0.05 \times 0.05 \mathrm{~m}$ cylinders to determine the CSWRC, penetration resistance (PR) and intrinsic soil air permeability $\left(K_{\text {air }}\right)$.

It should be noted that the difference in collecting the samples between the horizons was due to the thickness of the A horizon. In general, the average thickness of the A horizon in cohesive soils is $0.20 \mathrm{~m}$, and in order to simulate more natural conditions, this characteristic was considered when planning the experiment.

However, the A horizon of the soil selected for collection had a thickness of $0.17 \mathrm{~m}$; it was therefore decided to collect disturbed samples in order to prepare the column using a sufficient volume of soil to represent the same density seen under field conditions.

Two characteristic soil water retention curves were obtained, one for each horizon, at a pressure of $0,2,4,6$, $8,10,33,100,700$ and $1500 \mathrm{kPa}$. For the A horizon, the samples were prepared for a density of $1.360 \mathrm{~kg} \mathrm{~m}^{-3}$.

After each moisture level and respective pressure was determined, the curve was adjusted employing the mathematical model proposed by Van Genuchten (1980), using equation 2 :

$\theta=\theta_{r}+\frac{\theta_{s}-\theta_{r}}{\left[1+\left(\alpha\left|\varphi_{m}\right|\right)^{n}\right]^{m}}$

where $\theta$ corresponds to the water content $\left(\mathrm{m}^{3} \mathrm{~m}^{-3}\right) ; \theta_{r}$ and $\theta s$ are respectively, the residual and saturated water content $\left(\mathrm{m}^{3} \mathrm{~m}^{-3}\right) ; \phi m$ is the matric potential of water in the soil $(\mathrm{kPa}) ; \alpha$ a scalar for $\phi m ; m$ and $n$ are model adjustment parameters related to the shape of the curve.

To fit the data, the Table Curve 2D v 5.01 software was used (SYSTAT SOFTWARE INC., 2014). The values of $\theta r, \theta s, \alpha, n$ and $m$ for the A horizon were $0.07 \mathrm{~m}^{3} \mathrm{~m}^{-3}, 0.46 \mathrm{~m}^{3} \mathrm{~m}^{-3}, 0.46,0.55$ and 1.7 respectively, and for the cohesive $\mathrm{B}$ horizon, the values were 0.21 $\mathrm{m}^{3} \mathrm{~m}^{-3} ; 0.38 \mathrm{~m}^{3} \mathrm{~m}^{-3}, 0.36,0.15$ and 3.96 respectively. 
Bulk density and microporosity (Mi) were determined as per methods described in Teixeira et al. (2017). The porosity was obtained using equation 3:

$$
\mathrm{PT}=1-\mathrm{Ds} / \mathrm{Dp}
$$

where PT is the porosity $\left(\mathrm{m}^{3} \mathrm{~m}^{-3}\right)$; Ds and Dp are the bulk density and particle density $\left(\mathrm{kg} \mathrm{m}^{-3}\right)$ respectively. The macroporosity $(\mathrm{Ma})$ was determined from the difference between PT and Mi. The values obtained for the A horizon were $1.360 \mathrm{~kg} \mathrm{~m}^{-3}$ for Ds, and $0.460,0.255$ and $0.205 \mathrm{~m}^{3} \mathrm{~m}^{-3}$ for PT, Ma and Mi respectively. For the cohesive B horizon, the values were $1.520 \mathrm{~kg} \mathrm{~m}^{-3}$ for Ds, and $0.385,0.068$ and $0.317 \mathrm{~m}^{3} \mathrm{~m}^{-3}$ for PT, Ma and Mi respectively.

The penetration resistance was determined in samples where the water content corresponded to a pressure of $10 \mathrm{kPa}$, using a static electronic bench penetrometer (Marconi model MA-933). The determined resistance value was $1.80 \mathrm{MPa}$.

The particle-size analysis and chemical analysis were carried out as per the methods described in Teixeira et al. (2017). Horizon A had a particle-size distribution of $816 \mathrm{~g} \mathrm{~kg}^{-1}$ sand, $93 \mathrm{~g} \mathrm{~kg}^{-1}$ silt and $91 \mathrm{~g} \mathrm{~kg}^{-1}$ clay, a textural class of loamy sand, and the following chemical characteristics: $\mathrm{EC}=0.38 \mathrm{dS} \mathrm{m}^{-1}, \mathrm{pH}=5.27$ (Water), $\mathrm{P}$ $=5.29 \mathrm{mg} \cdot \mathrm{kg}^{-1}, \mathrm{Ca}^{2+}=1.2, \mathrm{Mg}^{2+}=0.50, \mathrm{~K}^{+}=0.07, \mathrm{Na}^{+}$ $=0.06, \mathrm{Al}^{3+}=0.10$ and $\mathrm{H}^{+}=2.06 \mathrm{cmol}_{\mathrm{c}} \cdot \mathrm{kg}^{-1}$. For the B horizon the silt, sand and clay content was 556, 77 and 367 $\mathrm{g} \mathrm{kg}^{-1}$ respectively; $\mathrm{EC}=0.25 \mathrm{dS} \mathrm{m}^{-1}, \mathrm{pH}=4.61$ (Water), $\mathrm{P}$ $=0.50 \mathrm{mg} \cdot \mathrm{kg}^{-1}, \mathrm{Ca}^{2+}=0.80, \mathrm{Mg}^{2+}=0.70, \mathrm{~K}^{+}=0.03, \mathrm{Na}^{+}$ $=0.08, \mathrm{Al}^{3+}=0.45$ and $\mathrm{H}^{+}=2.05 \mathrm{cmol} \cdot \mathrm{kg}^{-1}$.

\section{Preparing the soil columns and experimental design}

Each experimental unit consisted of one soil column made from PVC $(0.4 \times 0.2 \mathrm{~m})$ with one plant per column. The columns were set up in the experimental area, with half the height comprising the A horizon $(0.2 \mathrm{~m})$ and the other half the B horizon $(0.2 \mathrm{~m})$. The $0.20 \mathrm{~m}$ of PVC necessary for the A horizon was affixed immediately above the half corresponding to the B horizon, using highly adhesive tape. The weight required to make up the volume was calculated, fixing the density at a value of 1.400 $\mathrm{kg} \mathrm{m}^{-3}$ (previously determined when the soil was collected). A cheesecloth, an anti-aphid screen and a plastic plate to avoid soil loss were placed at the bottom of each column.

The experimental design was of completely randomised blocks (RBD), with five levels of aeration porosity (AP) $\left(0.04,0.06,0.09,0.11\right.$ and $\left.0.13 \mathrm{~m}^{3} \mathrm{~m}^{-3}\right)$ and six replications, giving a total of 30 experimental units.

\section{Conducting the experiment and carrying out the analyses}

To guarantee the established values for aeration porosity, the moisture and matric potential were calculated from the CSWRC for each treatment to control the AP. In one replication of each treatment, two tensiometers with a mercury manometer were installed at the centre of each horizon (A and B).

Three maize seeds (cultivar BRS 2022) were sown in each column; after 12 days the plants were thinned out. Fertilisation was via a nutritive solution based on the soil analysis. The $\mathrm{N}$ content was corrected to $30 \mathrm{mg} \mathrm{dm}^{-3}$ (ammonium sulphate), $\mathrm{P}$ to $30 \mathrm{mg} \mathrm{dm}^{-3}$ (monoammonium phosphate), $\mathrm{K}$ to $90 \mathrm{mg} \mathrm{dm}^{-3}$ (potassium chloride), $\mathrm{Mg}$ to $37.5 \mathrm{mg} \mathrm{dm}^{-3}$ (magnesium sulphate), $\mathrm{Zn}$ to $3 \mathrm{mg} \mathrm{dm}^{-3}$ (zinc sulphate), Fe to $4 \mathrm{mg} \mathrm{dm}^{-3}$ (Rexolin), Bo to $1.4 \mathrm{mg} \mathrm{dm}^{-3}$ (boric acid), Mn to $2.5 \mathrm{mg} \mathrm{dm}^{-3}$ (manganese sulphate), $\mathrm{Cu}$ to $2 \mathrm{mg} \mathrm{dm}^{-3}$ (copper sulphate), $\mathrm{Ca}$ to 3 $\mathrm{cmol}_{\mathrm{c}} \mathrm{dm}^{-3}$ (calcium chloride) and $\mathrm{Mg}$ to $1 \mathrm{cmol}_{\mathrm{c}} \mathrm{dm}^{-3}$ (magnesium sulphate).

To control the moisture content for each level of aeration porosity, 10 daily observations were made at hourly intervals of the height of the mercury column in each tensiometer. The water volume in the columns was replaced manually whenever necessary based on the CSWRC, using a measuring cylinder and tap water to maintain the AP.

To quantify the volume of water to be replaced, the volume calculated for the $\mathrm{A}$ and $\mathrm{B}$ horizons individually were added together. For the A horizon: moisture at field capacity $(\mathrm{CC}$ in $-10 \mathrm{kPa})$ - current moisture $\mathrm{x}$ volume of the A horizon column; for the B horizon: moisture level of each treatment - actual moisture $\mathrm{x}$ volume of the B horizon.

Evaluations were made of gas exchange [photosynthesis $(A)$, stomatal conductance $(g s)$, transpiration $(E)$ and internal $\mathrm{CO}_{2}$ concentration $\left.(C i)\right] 28$ and 39 days after seedling emergence, using an infrared gas analyser - IRGA (model LI-6400XT, Licor Biosciences Inc., Lincoln, Nebraska, USA) with an artificial source of radiation of $1200 \mu \mathrm{mol} \mathrm{m} \mathrm{m}^{-2} \mathrm{~s}^{-1}$, at room temperature and ambient $\mathrm{CO}_{2}$ concentration. The readings were taken on the fourth completely expanded leaf from the apex of the plant between 08:00 and 10:00. The intrinsic water use efficiency (WUEint) was calculated from the $A / g s$ ratio and the carboxylation efficiency $(\mathrm{EiC})$ from the $\mathrm{A} / \mathrm{C} i$ ratio (FERRAZ et al., 2012). The mean value of each evaluation was calculated to evaluate the gas exchange data,

The intrinsic soil air permeability in the cohesive B horizon was obtained in the laboratory using a completely randomised design. The analysis was carried out following the principle of decreasing pressure, balanced at pressures corresponding to an aeration porosity of $0.04,0.06$, $0.09,0.11$ and $0.13 \mathrm{~m}^{3} \mathrm{~m}^{-3}$. The PermeAr v.1.0 software (SILVEIRA et al., 2011) was used to record the fall in pressure over time. The air permeability coefficient $\left(K_{a i r}\right)$ was determined using equation 4 : 
$K_{\text {air }}=\frac{L \eta V}{A P_{a t m}} \times|S|$

where $K_{\text {air }}$ is the air permeability coefficient $\left(\mathrm{m}^{2}\right), \mathrm{V}$ the volume of air passing through the cylinder $\left(\mathrm{m}^{3}\right), \eta$ the dynamic viscosity of the air (Pa.s), L the height of the volumetric ring $(\mathrm{m}), A$ the cross section of the soil sample $\left(\mathrm{m}^{2}\right), P_{\text {atm }}$ the local atmospheric pressure (Pa) and $S$ the linear regression slope for pressure (ln pressure) as a function of time.

\section{Statistical analysis}

The resulting data were submitted to the Kolmogorov-Smirnov test to verify the assumptions of normality; if meeting the test criteria, the soil and plant data were submitted to regression analysis at $5 \%$ by F-test using the SISVAR software (FERREIRA, 2010).

\section{RESULTS AND DISCUSSION}

The data on the variation in area available to the flow of air in the soil, represented by the intrinsic soil air permeability $\left(K_{\text {air }}\right)$, showed a positive linear correlation, indicating that with the increase in aeration porosity there was an increase in the area available for gas exchange between the soil and the atmosphere (Figure 1).

The relationship shown in Figure 1 demonstrates that the increase in aeration porosity and, consequently, in the water leaving the pores, allowed the air to pass more easily through the soil. Considering the physical environment and plant growth, such behaviour allows for different perspectives. In the situation where the soil showed the least number of pores containing air

Figure 1 - Intrinsic soil air permeability $\left(\mathrm{K}_{\text {air }}\right)$, in the cohesive B horizon at different levels of aeration porosity

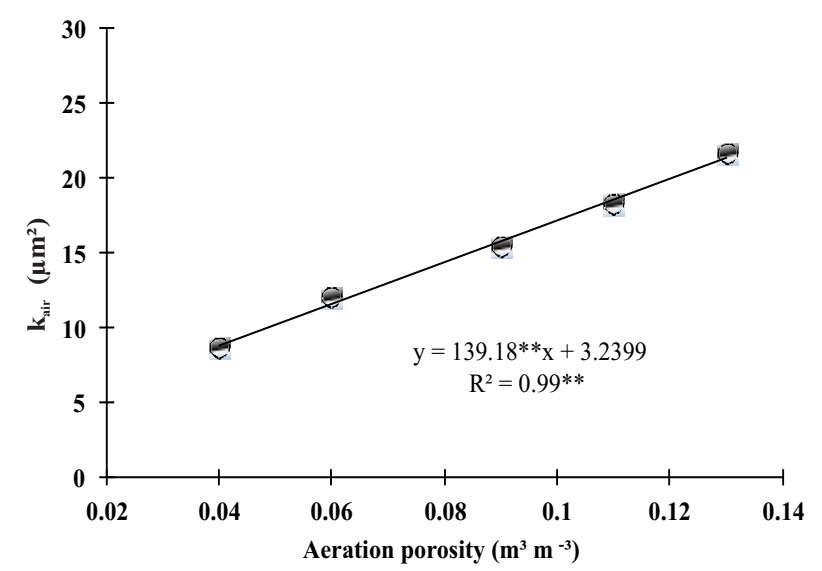

$(* *)$ in the regression equations indicate significance at $5 \%$ probability $\left(0.04 \mathrm{~m}^{3} \mathrm{~m}^{-3}\right)$ and, therefore, less area available for flow, despite not having restricted that flow, i.e. not causing values equal to zero, this reduction may still compromise processes essential for plant development.

On the other hand, the largest area available for flow $\left(0.13 \mathrm{~m}^{3} \mathrm{~m}^{-3}\right)$, despite being the most favourable condition for gas exchange to take place with no restrictions between the soil and the immediate atmosphere, other direct factors that can compromise plant development, such as the pressure at which water is retained in the soil and the mechanical resistance to root penetration, may be limiting factors.

Menezes et al. (2018), in a study of cohesive and non-cohesive soils, found that, irrespective of the soil, a reduction in moisture reflected an increase in $K_{\text {air }}$; however this reduction was more marked in the cohesive soil. The authors also reported that this can limit root exploitation of the soil and reduce the flow of air in the soil.

It is common for the water content of all soils to be affected by a variation in the pore space containing air, this is because the removal of one promotes the entry of the other. It should however be noted that the amount of variation depends on the characteristics of each soil.

Therefore, characteristics common to cohesive soils, such as the close arrangement of the particles, the large number of poorly connected and discontinuous micropores, high density and resistance to penetration (DANIELLS, 2012; MENEZES, et al., 2018; MOTA et al., 2018) may reduce pore functionality and efficiency in moving air and water in the soil, enhancing the effects on plant development of variations in the fraction of pores containing air.

For photosynthesis $(A)$, there is a significant fit to the quadratic model as a function of the level of aeration porosity (Figure 2a). The lowest values for $A$ were seen at an AP of $0.04 \mathrm{~m}^{3} \mathrm{~m}^{-3}\left(24.54 \mu \mathrm{mol} \mathrm{CO} \mathrm{m}^{2} \mathrm{~s}^{-1}\right)$ and $0.13 \mathrm{~m}^{3} \mathrm{~m}^{-3}(25.50$ $\left.\mu \mathrm{mol} \mathrm{CO}_{2} \mathrm{~m}^{2} \mathrm{~s}^{-1}\right)$. These values represent a respective reduction of $11.02 \%$ and $7.5 \%$ in relation to the point of maximum photosynthesis $\left(27.58 \mu \mathrm{mol} \mathrm{CO} \mathrm{C}^{2} \mathrm{~s}^{-1}\right.$, at an aeration porosity of $\left.0.089 \mathrm{~m}^{3} \mathrm{~m}^{-3}\right)$.

Stomatal conductance $(g s)$ showed a decreasing linear response to the levels of aeration porosity (Figure 2b), with a reduction in mean value of $18 \%$ from the highest to the lowest level of aeration porosity. Similar behaviour was seen for transpiration (Figure 2c), which also showed the highest mean value at the lowest level of aeration porosity $\left(0.04 \mathrm{~m}^{3} \mathrm{~m}^{-3}\right)$, equivalent to 5.52 mmol $\mathrm{H}_{2} \mathrm{O} \mathrm{m}^{2} \mathrm{~s}^{-1}$. In the treatment with $0.13 \mathrm{~m}^{3} \mathrm{~m}^{-3}$ the rate of transpiration was $4.77 \mathrm{mmol}_{2} \mathrm{O} \mathrm{m}^{2} \mathrm{~s}^{-1}$. This value corresponds to a reduction of $13.6 \%$ compared to the mean value seen for aeration porosity, of $0.04 \mathrm{~m}^{3} \mathrm{~m}^{-3}$. 
Figure 2 - Photosynthesis: $A$ (a); Stomatal conductance: gs (b); Transpiration: E (c); Internal $\mathrm{CO}_{2}$ concentration: Ci (d) in maize plants submitted to different levels of soil aeration porosity
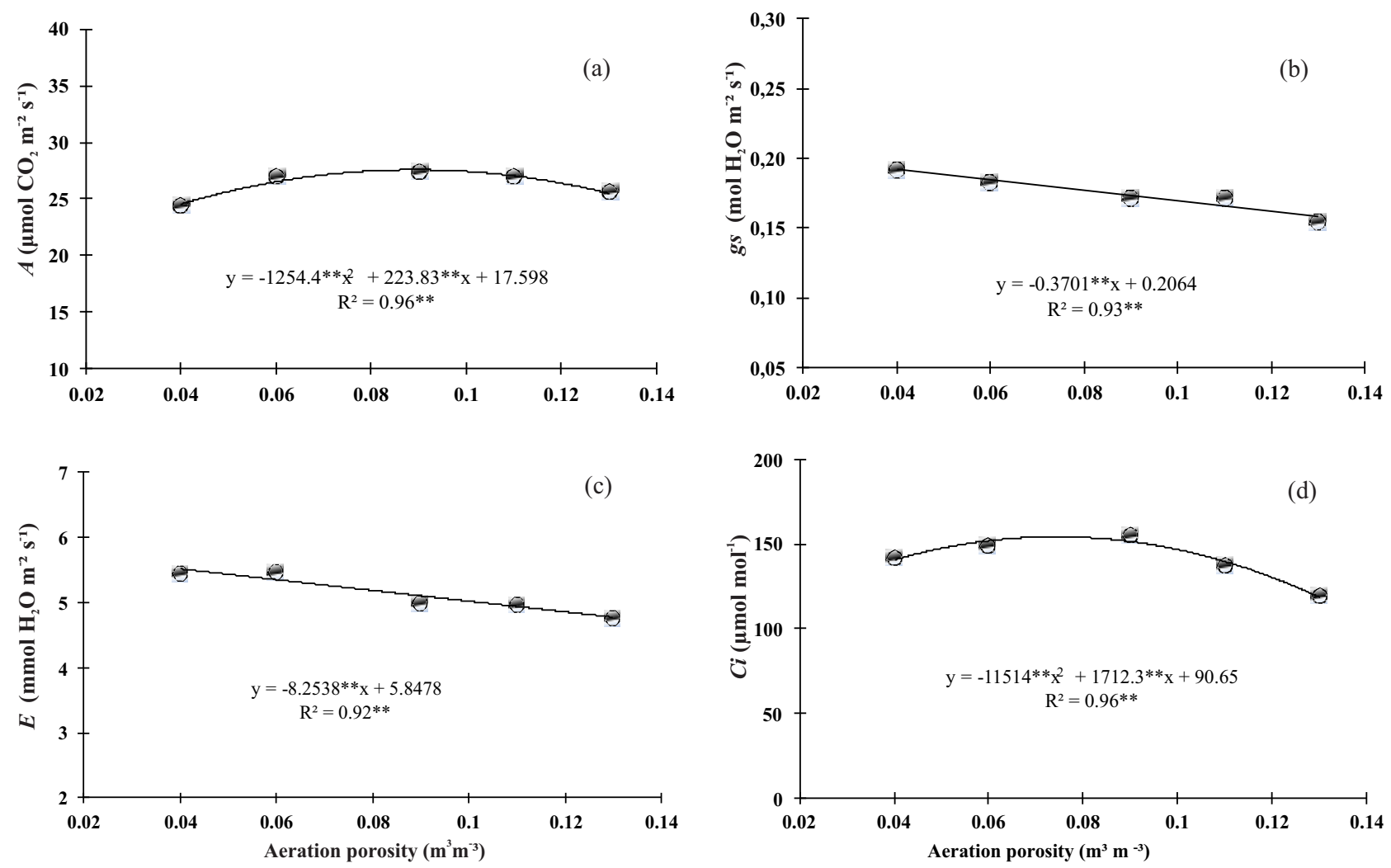

(**) in the regression equations indicate significance at $5 \%$ probability

In Figure 2, a quadratic effect can also be seen from the levels of aeration porosity on the internal $\mathrm{CO}_{2}$ concentration (Ci). Starting from the point of maximum $\mathrm{Ci}^{2}(154.09 \mu \mathrm{mol}$ $\mathrm{mol}^{-1}$, at an aeration porosity of $\left.0.07 \mathrm{~m}^{3} \mathrm{~m}^{-3}\right)$, there was a reduction of $8.7 \%$ in relation to the AP of $0.04 \mathrm{~m}^{3} \mathrm{~m}^{-3}(140.72$ $\mu \mathrm{mol} \mathrm{\textrm {mol } ^ { - 1 }}$ ) and of $23 \%$ when compared with the mean value for AP of $0.13 \mathrm{~m}^{3} \mathrm{~m}^{-3}\left(118.66 \mu \mathrm{mol} \mathrm{mol}{ }^{-1}\right)$.

The photosynthetic process depends on highly coordinated steps that begin with the roots absorbing water, which, upon reaching the leaves, becomes the force required for opening the stomata and capturing $\mathrm{CO}_{2}$ (TAIZ et al., 2017). However, for this process to occur properly, it is necessary for there to be a partition between the water and air content of the soil, this is because an excess of water due to a reduction in soil aeration, is as limiting to the plants as a lack of water (MORALES-OLMEDO; ORTIS; SELLES, 2015).

Under restricted aeration, the amount of oxygen to serve as the final electron acceptor during the end phase of oxidative respiration is insufficient, reflecting in less energy produced in the form of ATP (Adenine Triphosphate) (TAIZ et al., 2017; ZHOU et al., 2020). This situation, among others, can reduce water absorption by the roots and turgor pressure in the cells, causing stomatal closure and a drop in the photosynthetic rate due to stomatal limitation.

In addition to the stomata, low soil aeration can also reduce the photosynthetic rate due to biochemical factors when photosynthetic mechanism is damaged due to less efficient electron transport in the thylakoids (TAIZ et al., 2017; XIAOLING et al., 2011).

As such, it can be shown that the reduction in the photosynthetic rate of the plants subjected to a lower level of aeration porosity (Figure $2 \mathrm{a}$ ) occurred as a result of non-stomatal limitations due to physical conditions that are more restrictive to the flow of air in the soil, such as the low volumetric air content of the pores together with the smaller area available to the $K_{\text {air }}$ flow (Figure 1), since stomatal conductance did not prove to be a limiting factor (Figure 2b).

At an aeration porosity of $0.04 \mathrm{~m}^{3} \mathrm{~m}^{-3}$, the amount of water in the soil was sufficient to maintain water absorption and the turgidity of the guard cells, opening the stomata, reducing resistance to water leaving the leaf and, consequently, increasing the amount of water lost through 
transpiration, as shown by Figures $2 \mathrm{~b}$ and $2 \mathrm{c}$. however, this did not reflect in an increase in photosynthesis.

Another factor that demonstrates the repercussion of low soil aeration at the lowest aeration porosity on biochemical factors that limit photosynthesis, is the trend seen for internal $\mathrm{CO}_{2}$ concentration $(\mathrm{Ci})$ and the inverse behaviour between this and stomatal opening (Figure 2b, d). A reduction in the internal $\mathrm{CO}_{2}$ concentration together with a high level of stomatal opening, but with no increase in photosynthesis, indicates the capture of carbon, which for biochemical reasons was not used by the enzyme carboxylase RuBisCo (Ribulose 1.5 bisphosphate carboxylase-oxygenase) at the carboxylation sites (SILVA et al., 2015).

Tian et al. (2019), found a reduction in the photosynthetic rate of maize plants grown in the field and subjected to different periods of soil hypoxia. In this case, the authors reported a reduction in photosynthesis for an increase in the oxygen deficit, and attributed this to non-stomatal limitations.

Grzesiak et al. (2016), studying maize plants, also found a reduction in photosynthesis when using flooded and compacted soil (structurally similar to cohesive soil), and attributed this response to the effects of compaction on the process of soil aeration and in reducing the flow of air to the root system.

For the data observed at the greatest aeration porosity $\left(0.13 \mathrm{~m}^{3} \mathrm{~m}^{-3}\right)$ (Figure $2 \mathrm{a}$ ), it is worth noting that, despite this level of porosity presenting physical conditions that were more favourable to the flow of air in the soil, the soil water content was reduced with the increase in aeration porosity, possibly limiting water absorption by the plants, which, as a strategy to prevent water loss through transpiration, then closed the stomata (Figure 2b, c).

Under a water deficit, abscisic acid concentrations are increased, the hormone being transported from the roots towards the shoots via the xylem and inducing stomatal closure (SALAZAR; HERNÁNDEZ; PINO, 2015). Once the stomata are closed, $\mathrm{CO}_{2}$ diffusion to the sub-stomatal chambers is limited, resulting in a lower internal $\mathrm{CO}_{2}$ concentration (CHAVARRIA; SANTOS, 2012) and consequently a smaller volume of substrate for the photosynthetic process to occur (Figure 2a, b, c, d).

Furthermore, at this porosity, it was found that the roots exploit only the first few centimetres of the cohesive B horizon, indicating that other factors that directly affect the plants, such as penetration resistance, may have limited the volume of soil exploited by the roots and, consequently, water absorption (DANIELLS, 2012).

From the data shown, and considering the consensus that the range of moisture used to maintain the levels of aeration porosity in the cohesive B horizon is not restrictive to plant development, it can be inferred that the physical limitations resulting from the characteristics of cohesive soil may have enhanced the observed effects, particularly photosynthesis.

For the levels of aeration porosity from 0.06 to $0.11 \mathrm{~m}^{3} \mathrm{~m}^{-3}$, it should be noted that despite the tendency for a reduction in stomatal conductance, the internal $\mathrm{CO}_{2}$ concentration was higher, as was photosynthesis (Figure 2a, b, d), indicating that at these levels of porosity, $\mathrm{CO}_{2}$ influx from the external environment occurred with no major restrictions, and with no biochemical limitations on the photosynthetic process.

Instantaneous carboxylation efficiency (EiC) showed a linear increase as a function of aeration porosity (Figure 3a), with an aeration porosity of 0.04 and $0.13 \mathrm{~m}^{3} \mathrm{~m}^{-3}$ reflecting the lowest and highest mean value respectively, 0.17 and $0.21 \mu \mathrm{mol} \mathrm{m} \mathrm{m}^{-1}$ (an increase of 19\%).

At the lowest aeration porosity, this behaviour is associated with a lower photosynthetic rate and a higher internal $\mathrm{CO}_{2}$ concentration compared to the treatment of $0.13 \mathrm{~m}^{3} \mathrm{~m}^{-3}$. Considering that at the lowest AP the $\mathrm{Ci}$ decreased only $8.7 \%$ in relation to the point of greatest internal $\mathrm{CO}_{2}$ concentration, it can be inferred that there was sufficient substrate available to carry out photosynthesis, however, no photosynthetic response was seen in relation to this internal $\mathrm{CO}_{2}$ concentration, indicating problems of a non-stomatal nature (PEREIRA et al., 2004) since stomatal opening was not a limiting factor in this treatment (Figure 2b, 3a).

At the aeration porosity of $0.13 \mathrm{~m}^{3} \mathrm{~m}^{-3}$, a more pronounced drop in $\mathrm{Ci}$ can be seen $(23 \%$ in relation to the point of greatest $\mathrm{CO}_{2}$ concentration), without, however, showing a sharp reduction in $A$, which reflected in a greater value for $E i C$; in this case, stomatal opening was less, and probably limited $\mathrm{CO}_{2}$ entry to the stomata (Figure 2b, 3a). It should be noted that the $\mathrm{EiC}$ is strongly associated with the intracellular $\mathrm{CO}_{2}$ concentration and the rate of carbon dioxide assimilation (FERRAZ et al., 2012; MACHADO et al., 2005), so that any change in these variables has a positive or negative influence on the EiC.

The levels of aeration porosity also reflected in a linear increase in intrinsic water use efficiency (WUEint) (Figure $3 \mathrm{~b}$ ). In the treatment of $0.04 \mathrm{~m}^{3} \mathrm{~m}^{-3} \mathrm{AP}$, the value was $135.14 \mu \mathrm{mol} \mathrm{CO}_{2} \mathrm{~mol} \mathrm{H}_{2} \mathrm{O}^{-1}$, while for the AP of $0.13 \mathrm{~m}^{3} \mathrm{~m}^{-3}$, the plants were more efficient, with a mean value of $171.32 \mu \mathrm{mol} \mathrm{CO} \mathrm{mol} \mathrm{H}_{2} \mathrm{O}^{-1}$ (an increase of $21 \%$ in relation to the treatment with the smallest AP).

Such behaviour shows that the lowest photosynthetic rate found at the aeration porosity of 0.04 $\mathrm{m}^{3} \mathrm{~m}^{-3}$ was not a consequence of diffusive processes, but of biochemical processes, which can be confirmed by the 
Figure 3 - Instant carboxylation efficiency: EiC (a); Intrinsic water use efficiency: WUEint (b) in maize plants submitted to different levels of soil aeration porosity

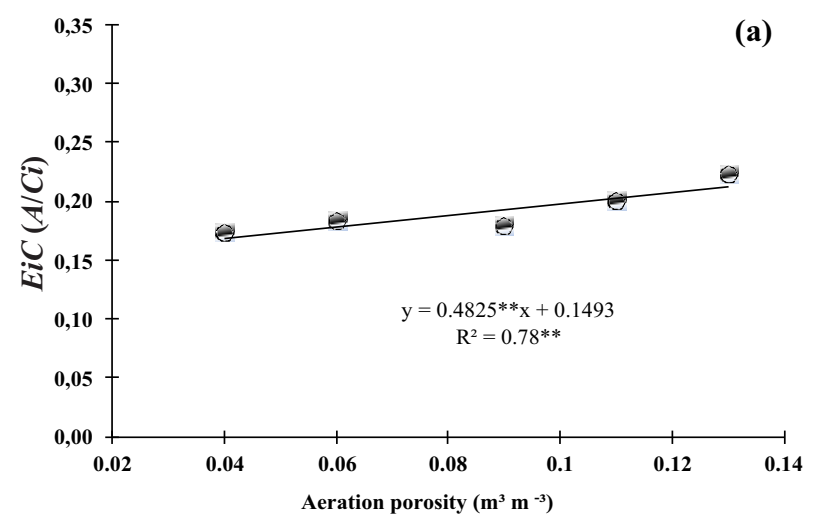

$(* *)$ in the regression equations indicate significance at $5 \%$ probability

lower value for $\mathrm{EiC}$ (Figure 3a). On the other hand, for the AP of $13 \mathrm{~m}^{3} \mathrm{~m}^{-3}$, the greatest value for WUEint is associated with the lowest stomatal conductance.

Silva et al. (2013), studying sugar cane, also found a greater WUEint for a treatment including water restrictions, attributing this to the inverse relationship between stomatal conductance and the WUEint. It is worth noting that in the present study, despite the soil water conditions not being characteristic of severe water restriction, evidence of the start of this stress could be seen, as is confirmed by the behaviour of WUEint.

\section{CONCLUSIONS}

1. The variation in aeration porosity in cohesive soils affected gas exchange in maize plants;

2. The lowest level of aeration porosity $\left(0.04 \mathrm{~m}^{3} \mathrm{~m}^{-3}\right)$ led to a reduction in the photosynthetic rate of the maize plants, probably related to non-stomatal limitations;

3. At the greatest aeration porosity $\left(0.13 \mathrm{~m}^{3} \mathrm{~m}^{-3}\right)$, the photosynthetic rate was also impaired, probably due to the reduction in soil water content with the increase in aeration porosity, which culminated in stomatal closure and a consequent reduction in $\mathrm{CO}_{2}$ entering the stomata;

4. The intermediate range of aeration porosity $(0.06,0.09$ and $0.11 \mathrm{~m}^{3} \mathrm{~m}^{-3}$ ) showed the highest photosynthetic rates in relation to the more extreme treatments, even with the reduction in stomatal conductance as the AP increased.

\section{ACKNOWLEDGEMENT}

This study was carried out with the support of the Coordenação de Aperfeiçoamento de Pessoal de Nível

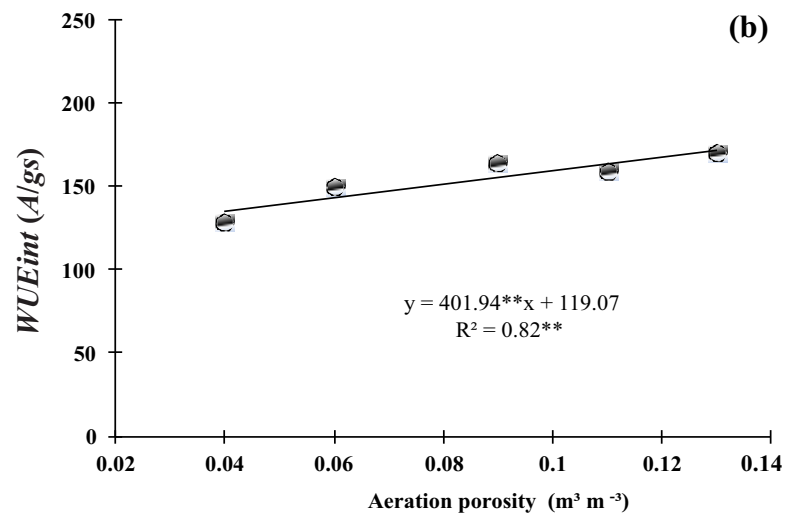

Superior (CAPES) through the Project for Pro-Integration (notice no. 55/2013).

\section{REFERENCES}

CHAVARRIA, G.; SANTOS, H. P. Plant water relations: absorption, transportand controlmechanisms.In:MONTANARO, G.; DICHIO, B. (org.). Advances in selected plant physiology aspects. Rijeka: Intech, 2012. v. 1, p. 105-132.

DANIELLS, I. G. Hardsetting soils: a review. Soil Research, V. 50, p. 349-359, 2012.

FERRAZ, R. L. de S. et al. Trocas gasosas e eficiência fotossintética em ecótipos de feijoeiro cultivados no semiárido. Pesquisa Agropecuária Tropical, v. 42, n. 2, p. 181-188, 2012.

FERREIRA, D. F. SISVAR®: Sistema de análise de variância para dados balanceados. Versão 5.5. Lavras: DEX/UFLA, 2010. (Software estatístico).

GRZESIAK, M. T. et al. Impact of soil compaction stress combined with drought or waterlogging on physiological and biochemical markers in two maize hybrids. Acta Physiologiae Plantarum, v. 38, n. 109, 2016.

MACHADO, E. C. et al. Respostas da fotossíntese de três espécies de citros a fatores ambientais. Pesquisa Agropecuária Brasileira, v. 40, n. 12, p. 1161-1170, 2005.

MENEZES, A. S. et al. Functionality of the porous network of Bt horizons of soils with and without cohesive character. Geoderma, v. 313, p. 290-297, 2018.

MORALES-OLMEDO, ORTIZ, M.; SELLÉS, G. Effects of transient soil waterlogging and its importance for rootstock selection. Chilean Journal of Agricultural Research, v. 75, 2015. Supplement 1.

MOTA, J. C. A. et al. Pore shape, size distribution and orientation in Bt horizons of two Alfisols with and without cohesive character from Brazil. Geoderma Regional, v. 15, p. e00197, 2018. 
PEREIRA, F. H. F. et al. Trocas gasosas em plantas de tomateiro submetidas a condições salinas. Horticultura Brasileira, v. 22, n. 2, 2004. Suplemento 2.

REZENDE, J. O. Solos coesos dos Tabuleiros Costeiros: limitações agrícolas e manejo. Salvador: SEAGRI - SPA, 2000. 117 p.

SALAZAR, C.; HERNÁNDEZ, C.; PINO, M. T. Plant water stress: associations between ethylene and abscisic acid response. Chilean Journal of Agricultural Research, v. 75, 2015.

SANTOS, H. G. et al. Sistema brasileiro de classificação de solos. 5. ed. rev. ampl. Brasília, DF: Embrapa, 2018. 353 p.

SILVA. F. G. et al. Trocas gasosas e fluorescência da clorofila em plantas de berinjela sob lâminas de irrigação. Revista Brasileira de Engenharia Agrícola e Ambiental, v. 19, n. 10, p. $946-952,2015$.

SILVA, M. de A. et al. Photosynthetic Capacity and water use efficiency in sugarcane genotypes subject to water deficit during early growth phase. Brazilian Archives of Biology and Technology, v. 56, p. 735-748, 2013.

SILVEIRA, L. R. et al. Sistema de aquisição de dados para equipamento de medida da permeabilidade intrínseca do solo ao ar. Revista Brasileira de Ciência do Solo, v. 35, p. 429-436, 2011.
SYSTAT SOFTWARE INC. Table Curve 2D. Trial Version 5.01. 2014. Disponível em: http://www.sigmaplot.com/products/ tablecurve2d/tablecurve2d.php. Acesso em: 30 jan. 2017.

TAIZ, L. et al. Fisiologia vegetal. 5. ed. Porto Alegre: Artmed, 2017. 888 p.

TEIXEIRA, P. C. et al. Manual de métodos de análise de solo. 3. ed. rev. e ampl. Brasília, DF: Embrapa, 2017. 574 p.

TIAN, L. et al. Effects of waterlogging stress at different growth stages on the photosynthetic characteristics and grain yield of spring maize (Zea mays L.) Under field conditions. Agricultural Water Management, v. 218, p. 250-258, 2019.

VAN GENUCHTEN, M. T. A closed form equation for predicting the conductivity of unsaturated soils. Soil Science Society of America Journal, v. 44, p. 892-897, 1980.

XIAOLING, LI et al. Morphological and photosynthetic responses of riparian plant Distylium chinense seedlings to simulated Autumn and Winter flooding in Three Gorges Reservoir Region of the Yangtze River, China. Acta Ecologica Sinica, v. 31, p. 31-39, 2011.

ZHOU, W. et al. Plant waterlogging/flooding stress responses: from seed germination to maturation. Plant Physiology and Biochemistry, v. 148, p. 228-236, 2020. 